\author{
UDC 616.441-006.6-089.163:577.175.4 \\ https://doi.org/10.32345/USMYJ.4(127).2021.68-76
}

Received: September 8,2021

Accepted: November 24,2021

\title{
THE ROLE OF CALCITONIN IN THE PREOPERATIVE STAGE AS THE PREDICTOR OF MEDULLARY THYROID CANCER METASTASES
}

\author{
Palamarchuk Volodymyr ${ }^{1}$, Smolyar Viktor ${ }^{1}$, Tovkay Oleksandr ${ }^{1}$, Nechay Oleksandr ${ }^{1}$, Kuts Volodymyr ${ }^{1,2}$, \\ Sichinava Revaz ${ }^{1}$, Mazur Oleh ${ }^{1}$ \\ ${ }^{1}$ Ukrainian Scientific and Practical Center for Endocrine Surgery, Transplantation of Endocrine Organs and \\ Tissues of the Ministry of Health of Ukraine, Kyiv, Ukraine \\ ${ }^{2}$ SI "National institute of pathophysiology and pulmonology named after F.G. Yanovsky of the NAMS of \\ Ukraine", Kyiv, Ukraine
}

\begin{abstract}
: the aim of the stydy was to analyze the detectability of medullary thyroid metastases in patients at treatment and diagnostic stages, to investigate the applicability of serum calcitonin level as predictor of possible presence of medullary thyroid metastases. The study included data from 148 patients who underwent surgical treatment for the initial diagnosis of medullary thyroid cancer. The age of patients ranged from 12 to 83 years, the mean age was 48,2 1,9 years; the distribution by gender was as follows: men - 34 (23\%), women - 114 (77\%). Patients were divided into two groups depending on the pathomorphological report: 1 group $(100(67,6 \%)$ - patients without metastases), 2 group (48 (32,4\%) - patients with locoregional metastases). Among 148 studied patients with medullary thyroid cancer, as a result of the histopathological conclusion, in $48(32,4 \%)$ metastases were detected in regional lymph nodes, among which $10(6,7 \%)$ patients had metastases only in the central collector and $38(25,7 \%)$-both in the central and lateral collectors. At the preoperative stage, the level of undiagnosed metastases by ultrasound was $64,58 \%$ (31 patients). Subsequently, at the intraoperative stage, during the rapid histological biopsy, the number of undiagnosed metastases decreased to 37,5\% (18 patients), and in the postoperative period, according to the results of histopathological examination, the remaining patients were diagnosed with the medullary thyroid cancer metastases. Ultrasound helped to detect metastases in 17 patients, which was 35,42\% of all detected metastases. At the stage of intraoperative study, the detection of metastases increased and amounted to $30(62,5 \%)$, and in the postoperative period as a result of histopathological examination metastases were confirmed in 48 patients (100\%). Quantitative indicators of both detected and undiagnosed metastases at all stages of treatment and diagnostic search are statistically significant $(p<0,01)$. The detection of metastases in the central lymphatic collector (N1a) at the preoperative stage was 2,08\%, this index has doubled (to 4,16\%) after intraoperative rapid histological conclusion, and after histopathological conclusion the index has increased more than 10 times $(20,84 \%)$. This tendency to grow of metastaseses detection was followed also on lateral collectors: N1b and psilateral were observed at $15(31,2 \%)$ patients at the preoperative stage, their number increased to $23(47,9 \%)$ intraoperatively and to 31 (64,6\%) postoperatively; N1b contralateral was observed in $1(2,1 \%), 5(10,4 \%)$ and $7(14,6 \%)$, respectively. Such a low percentage of metastases detection at the preoperative stage by ultrasound prompted to CT level study as the predictor of possible metastases. We investigated the preoperative basal blood CT value as a marker of the medullary thyroid cancer metastases presence probability. Due to the small number of the group $(n=10)$ with N1a, the association of CT (cut-off level $137 \mathrm{pg} / \mathrm{ml}$ ) with the possible presence of metastases was not significant $(A U C=0.594)$, while in the group with $\mathrm{Nlb}$ there was a more significant difference. Thus, CT cut-off levels of $358 \mathrm{pg} / \mathrm{ml}$ for N1b ipsilateral, and $498 \mathrm{pg} / \mathrm{ml}$ for N1b contralateral detection of possible metastases in collectors, with AUC: 0.877 and 0.832, respectively, which justifies the importance of the lateral neck dissection in addition to the mandatory central dissection in order to remov possible medullary thyroid cancer metastases. Thus, ultrasound is insufficiently reliable method of metastases verifying in medullary thyroid cancer $(D E=35.4 \%$ at $d \mathrm{mts}<0.6 \mathrm{~cm}$ ). In the absence of ultrasound data (or fine needle aspiration (FNA) biopsy results) on the presence of metastases to raise awareness of the disease prevalence, to clarify the prognosis of its development it's important to use the additional criterion - the calcitonin level. Basal calcitonin level is the reliable predictor of the medullary thyroid cancer metastases. Its cut-off level of $137 \mathrm{pg} / \mathrm{ml}$ indicates the possible presence of metastases in the central group (N1a) (AUC=0,594). The CT cut-off level $-358 \mathrm{pg} / \mathrm{ml}$ $(A U C=0,793)$ suggests the presence of the medullary thyroid cancer metastases $(N 1 a+N 1 b) . C T$ cut-off levels -358 $\mathrm{pg} / \mathrm{ml}$ for N1b ipsilateral, and $498 \mathrm{pg} / \mathrm{ml}$ for N1b contralateral (AUC: 0,877 and 0,832), respectively. The calculated values of the countersensitivity test to detect metastases for different levels of basal CT in the preoperative stage in the clinical setting will help the practitioner in deciding on treatment tactics to determine the extent of surgery in patients diagnosed (or suspected) with the medullary thyroid cancer metastases.
\end{abstract}


Key words: calcitonin, thyroid neoplasms, neoplasm metastasis, $\underline{\text { ROC Curve, thyroid gland. }}$

Introduction. Medullary thyroid cancer (MTC) is a rare type of the thyroid gland malignant tumor that originates from parafollicular cells (Master \& Burns, 2021), or C-cells derived from the neural crest, which produce calcitonin - a thyroid hormone that can be used as a specific marker of thyroid cancer (Park, et al., 2021). Despite the relatively infrequent occurrence of medullary thyroid cancer, which accounts for up to $5 \%$ of all cases of thyroid cancer (Miller, et al., 2018), it is the cause of a disproportionately large number of deaths (according to various sources $13.4 \%-38.0 \%$ ) (Kuo, et al., 2017) of patients with this pathology; the disease tends to metastasize rapidly, and it is refractory to modern methods of non-surgical treatment (Kebebew, et al., 2000). To date, surgery remains the main method of thyroid cancer treatment, and when planning the surgical scope (lymph dissection) at the preoperative stage, there is always the problem of probable metastases detection; however, existing methods of visualization (ultrasound, MSCT, PET-CT) do not have a sufficiently high diagnostic efficiency to verify metastases (Kouvaraki, et al., 2003; Kiesewetter, et al., 2021). The imperfection of the preoperative neck ultrasonography is possible to be one of the main reasons for the detection in the postoperative period of elevated calcitonin levels in more than half of patients with metastatic MTC (Van Heerden, et al., 1990). It is known that the recurrence and survival rate depend on the initial volume of the operation, and a better level of biochemical remission is the result of adequate neck dissection (Fleming, et al., 1999). Thyroidectomy with central neck dissection is recommended for almost all patients with MDR; however, indications for lateral dissection remain controversial (Roman, et al., 2006; Pelizzo, et al., 2007; Bartz-Kurycki, et al., 2021).

The possibility of the medullary thyroid cancer metastases predicting at the diagnostic and treatment stage, we present in our own work.

The aim of the stydy was to analyze the detectability of medullary thyroid cancer metastases in patients at treatment and diagnostic stages. To investigate the possibility of serum calcitonin using to predict the possible presence of medullary thyroid metastases and to determine the extent of surgery.

Materials and methods. The study included data from 148 patients who underwent surgical treatment at the Center for the initial diagnosis of medullary thyroid cancer. The age of patients ranged from 12 to 83 years, the mean age was $48.2 \pm 1.9$ years; the distribution by gender was as follows: men $-34(23 \%)$, women -114 $(77 \%)$. Patients were divided into two groups depending on the presence of metastases according to the pathomorphological study: 1 group $(100(67.6 \%)$ - patients without metastases), 2 group (48 (32.4\%) - patients with existing locoregional metastases.

All patients in the preoperative and postoperative stages were measured for basal serum calcitonin levels, its values were considered normal at $\leq 18 \mathrm{pg} / \mathrm{mL}$. The study was performed on the automatic immunochemiluminescent analyzer «MAGLUMI» (manufacturer «Snibe Diagnostic», China). Reagents from the same manufacturer were used. Ultrasound was also performed to establish the spread of the process.

Accumulation and primary data processing were performed in MS Excel 2013, statistical processing was performed using StatPlus (license \#21735752) and MedCalc (trial. ver.) Using descriptive statistics, parametric and nonparametric methods for testing statistical hypotheses (Student's criteria, Mann-Whitney, angular Fisher transform), conjugation tables analysis, ROC analysis. Depending on the type of distribution of the variation series, the results of the calculations are presented as the mean value and the standard error or median and the 25th and 75th percentiles (Me (Q25; Q75)). The results at $p<0.05$ were considered statistically significant.

\section{Results and discussion.}

1. The effectiveness of MTC locoregional metastases detection at the treatment and diagnostic stages.

Among 148 studied patients with thyroid cancer, 48 $(32,4 \%)$ as a result of pathohistological findings revealed metastases to regional lymph nodes, of which $10(6,7 \%)$ patients had metastases only in the central collector and in $38(25,7 \%)$ - both in the central in lateral collectors.

Table 1. Detectability of thyroid cancer metastases by ultrasound at different treatment and diagnostic stages

\begin{tabular}{|c|c|c|c|}
\hline $\begin{array}{l}\text { Presence Stage } \\
\text { of metastases }\end{array}$ & Preoperative & Intraoperative & Postoperative \\
\hline Nx & $31(64,58 \%)^{* *}$ & $18(37,5 \%)$ & 0 \\
\hline N1a & $1(2,08 \%)^{* *}$ & $2(4,16 \%)^{* *}$ & $10(20,84 \%)$ \\
\hline N1b ipsilateral & $15(31,26 \%)^{* *}$ & $23(47,92 \%)^{*}$ & $31(64,58 \%)$ \\
\hline N1b contralateral & $1(2,08 \%)^{* *}$ & $5(10,42 \%)$ & $7(14,58 \%)$ \\
\hline N1a,b & $17(35,42 \%)^{* *}$ & $30(62,5 \%)^{* *}$ & $48(100 \%)$ \\
\hline
\end{tabular}

$1 .{ }^{*}$ - the difference compared to the postoperative stage is significant $(\mathrm{p}<0,05)$;

2 . $* *$ - the difference compared to the postoperative stage is significant $(\mathrm{p}<0,01)$.. 
Table 2. The level of basal preoperative calcitonin as a predictor of metastases

\begin{tabular}{|c|c|c|}
\hline \multicolumn{2}{|c|}{ Observation parameters } & Primary MTC (\%) \\
\hline \multicolumn{2}{|c|}{$\sum$} & $148(76,3 \%)$ \\
\hline \multirow[t]{3}{*}{$\mathrm{N}$ stage } & $\mathrm{No}$ & $100(67,6 \%)$ \\
\hline & N1a & $10(6,8 \%)$ \\
\hline & N1в & $38(25,7 \%)$ \\
\hline \multirow{4}{*}{$\begin{array}{l}\text { Number of } \\
\text { metastatic lymph } \\
\text { nodes }\end{array}$} & $\begin{array}{l}\text { Average value } \\
\mathrm{M} \pm \mathrm{SE}\end{array}$ & $2,5 \pm 0,4$ \\
\hline & Number of cases $\mathrm{Na}, \mathrm{b} / \%$ & $49 / 33,3 \%$ \\
\hline & Median $\operatorname{Me}\left(Q_{25} ; Q_{75}\right)$ & $6,0(3,0 ; 10,0)$ \\
\hline & Range (minimum - maximum) & $0-24$ \\
\hline \multirow{2}{*}{$\begin{array}{l}\text { Preoperative calci- } \\
\text { tonin }\end{array}$} & Median $\mathrm{Me}\left(\mathrm{Q}_{25} ; \mathrm{Q}_{75}\right)$ & $456,4(136,4 ; 1267,50)$ \\
\hline & Range (minimum - maximum) & $4,92-6000,0$ \\
\hline
\end{tabular}

The presence of metastases at the preoperative stage by ultrasound was $11,5 \%$ (17 patients), and their subsequent detection at the treatment and diagnostic stages is shown in table 1.

The above data show that at the preoperative stage the level of undiagnosed metastases by ultrasound was $64,58 \%$ (31 patients). Subsequently, at the intraoperative stage, during rapid histological biopsy, the number of patients with undiagnosed metastases decreased to $37,5 \%$ (18 patients), and in the postoperative period, according to the results of histopathological findings, the remaining patients were diagnosed with MTC metastases. The use of ultrasound helped to detect metastases in 17 patients, which accounted for $35,42 \%$ of all detected metastases. At the stage of intraoperative examination, the metastases detection increased and amounted to 30 $(62,5 \%)$, and in the postoperative period, as a result of pathohistological findings, metastases were confirmed in 48 patients $(100 \%)$. Quantitative indicators of both detected and undiagnosed metastases at all stages of medical and diagnostic search are statistically significant $(p<0.01)$. The detection of metastases in the central lymphatic collector (N1a) at the preoperative stage was $2,08 \%$, this number doubled (to $4,16 \%$ ) after receiving the intraoperative rapid conclusion, and when obtaining the histopathological conclusion it increased more than 10 times $(20,84 \%)$. This tendency of metastaseses detection growth followed also on lateral collectors (N1b): N1b ipsilateral were observed at $15(31,2 \%)$ patients at the preoperative stage, their number increased to 23 $(47,9 \%)$ intraoperatively and to $31(64,6 \%))$ postoperatively; N1b contralateral was observed in $1(2,1 \%), 5$ $(10,4 \%)$ and $7(14,6 \%)$, respectively.

Thus, ultrasound, as the method that is most widely used for topical diagnosis of the MTC prevalence does not have the necessary diagnostic efficiency. False-negative ultrasound findings on the metastases presence are found more often in the central than in the lateral col- lector and when the size of metastases is $<0.6 \mathrm{~cm}$, their detection does not exceed $36 \%$, both due to the limited capabilities of the equipment and expressed author-dependence (Товкай та ін., 2020).

\section{The level of basal preoperative calcitonin as a predictor of metastases.}

Given the unsatisfactory result in the detection of thyroid metastases at the preoperative stage by ultrasound $(35,42 \%)$, we considered calcitonin as another predictor of metastases (Opsahl, et al., 2019).

For the group without metastases (N0) the level of calcitonin was in the range (minimum - maximum) 4,92 $-4234,0 \mathrm{pg} / \mathrm{mL}$, for the group with metastases only to the central collector (N1a): 63,3-5595, for the group with metastases in the central and lateral collectors (N1b) the range was $219-6000,0$. Thus, the range of preoperative calcitonin levels for both non-metastatic and metastatic tumors has large cross-sectional areas. To determine the possibility of using the level of calcitonin to determine it as a predictor of metastases, ROC analysis was performed (Fugazzola, et al., 2021; Giovanella, et al., 2021) and good quality models for all levels of metastases were identified (Fig. 1 a, b, c, d).

Therefore, we have the opportunity to determine the cut-off thresholds of cSealcitonin depending on the level of metastases and the main operational characteristics of this test (Table 3).

As can be seen from the above data, at a blood calcitonin level of $136,9 \mathrm{pg} / \mathrm{mL}$, the possibility of detecting metastases to the central lymphatic collector (N1a) is not have a highly significant: the area under the curve (AUC) is 0,594 . This may be due to the small sample size $(n=10)$. The cut-off level of calcitonin was $137 \mathrm{pg} /$ $\mathrm{mL}$ for the presence of possible MTC metastases in N1a. The relationship between calcitonin levels and the detection of MTC metastases in lateral collectors (N1b) was more significant. Thus, the cut-off level of calcitonin for possible ipsilateral (N1b) metastases was $358 \mathrm{pg} / \mathrm{mL}$, 

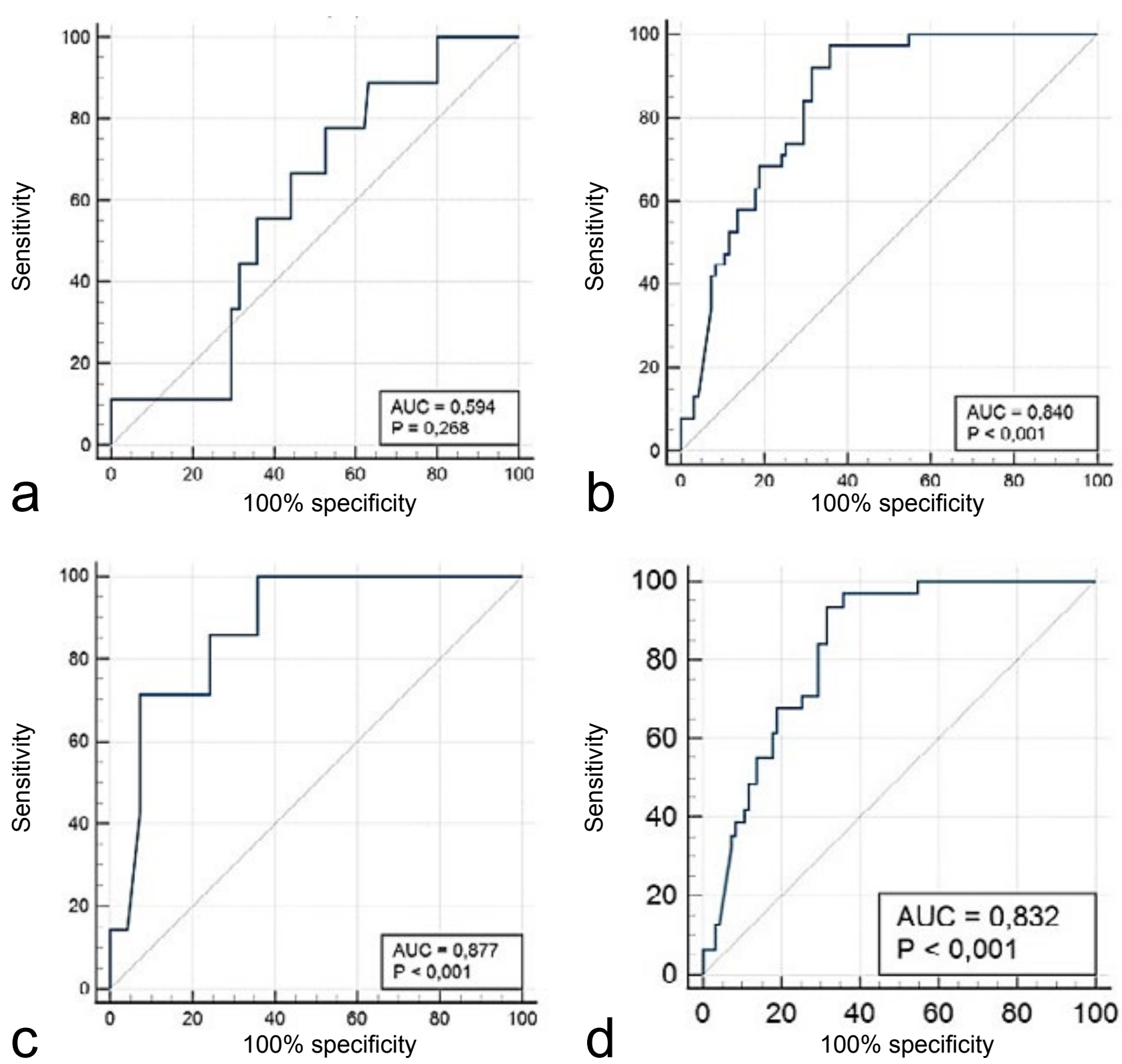

Fig. 1. ROC curve, the relation of preoperative calcitonin levels with the metastases presence: a) in the central collector $(n=0) ; b)$ in the lateral lymphatic collectors $(n=38)$; c) in the ipsilateral collector $(n=31)$; d $)$ in the contralateral lymphatic collector $(\mathrm{n}=7)$.

\begin{tabular}{|l|c|c|c|c|c|}
\hline The level of metastases & Cut-off, pg/mL & AUC & Youden's Index J & Sensitivity & Specificity \\
\hline N1a, $n=10$ & 136,9 & 0,594 & 0,257 & 0,889 & 0,368 \\
\hline N1b, $\mathrm{n}=38$ & 358 & 0,840 & 0,616 & 0,974 & 0,642 \\
\hline N1b, ipsilateral, $\mathrm{n}=31$ & 358 & 0,877 & 0,642 & 1,000 & 0,642 \\
\hline N1b contralateral, $\mathrm{n}=7$ & 498 & 0,832 & 0,620 & 0,936 & 0,684 \\
\hline$\sum(\mathrm{N} 1 \mathrm{a}, \mathrm{N} 1 \mathrm{~b}), \mathrm{n}=48$ & 358 & 0,793 & 0,535 & 0,894 & 0,642 \\
\hline
\end{tabular}

Table 3. Thresholds of cut-off values of preoperative blood calcitonin depending on the extention of metastases. The main operational characteristics of the test 


\begin{tabular}{|c|c|c|c|}
\hline $\begin{array}{c}\text { Preoper- } \\
\text { ational } \\
\text { calcitonin, } \\
\text { pg/mL }\end{array}$ & $\begin{array}{c}\text { False } \\
\text { negative } \\
\text { sensitivity, } \\
\text { CoSe }\end{array}$ & $\begin{array}{c}\text { Preoper- } \\
\text { ational } \\
\text { calcitonin, } \\
\text { pg/mL }\end{array}$ & $\begin{array}{c}\text { False } \\
\text { negative } \\
\text { sensitivity, } \\
\text { CoSe }\end{array}$ \\
\hline 60,7 & 0,000 & 980,8 & 0,426 \\
\hline 63,5 & 0,021 & 1054,0 & 0,447 \\
\hline 147,5 & 0,043 & 1059,0 & 0,468 \\
\hline 220,0 & 0,064 & 1076,5 & 0,489 \\
\hline 228,1 & 0,085 & 1086,0 & 0,511 \\
\hline 314,5 & 0,106 & 1267,5 & 0,532 \\
\hline 365,6 & 0,106 & 1293,5 & 0,553 \\
\hline 377,7 & 0,128 & 1447,5 & 0,574 \\
\hline 385,4 & 0,149 & 1478,0 & 0,596 \\
\hline 410,2 & 0,170 & 1716,0 & 0,638 \\
\hline 506,7 & 0,191 & 1854,2 & 0,660 \\
\hline 511,7 & 0,213 & 1965,5 & 0,681 \\
\hline 516,3 & 0,255 & 1990,0 & 0,702 \\
\hline 546,1 & 0,277 & 2182,5 & 0,872 \\
\hline 557,5 & 0,298 & 2576,2 & 0,894 \\
\hline 573,4 & 0,319 & 3082,7 & 0,915 \\
\hline 582,1 & 0,340 & 5297,5 & 0,936 \\
\hline 619,5 & 0,362 & 5614,0 & 0,957 \\
\hline 674,0 & 0,383 & 5816,5 & 0,979 \\
\hline 870,5 & 0,404 & 6001,0 & 1,000 \\
\hline
\end{tabular}

Table 4. Correspondence of preoperative blood calcitonin level and false negative sensitivity in patients with medularly thyroid cancer

and for contralateral metastases $(\mathrm{N} 1 \mathrm{~b})-498 \mathrm{pg} / \mathrm{mL}$, with a sufficiently high AUC: 0,87 and 0,82 , respectively. In general, for lateral metastases, the AUC was 0,783 with the cut-off calcitonin level of $358 \mathrm{pg} / \mathrm{mL}$.

Therefore, the possibility of using ROC analysis to predict the presence of MTC metastases depending on the level of preoperative calcitonin has been proven; numerical values of false negative sensitivity calculated, i.e. the probability of obtaining a negative test result in patients with metastases, for different cut-off thresholds (Table 4).

There is a possibility to get a negative test result in the patient (in our case - to miss metastases). When the test threshold (calcitonin value) is low, we can potentially detect all cases of metastases, i.e. the sensitivity of the test is $100 \%$ (there will be a pre-diagnosis) (Palamarchuk,2020). At the same time false negative sensitivity is zero (as shown by the graph in Fig. 2).

The calculated values of countersensitivity show a change in the probability of the negative test result obtaining in patients with metastases. Thus, when the basal calcitonin level is obtained in the patient with MTC, or if this type of tumor is suspected, the practitioner has the opportunity to determine and assess the expected proba-

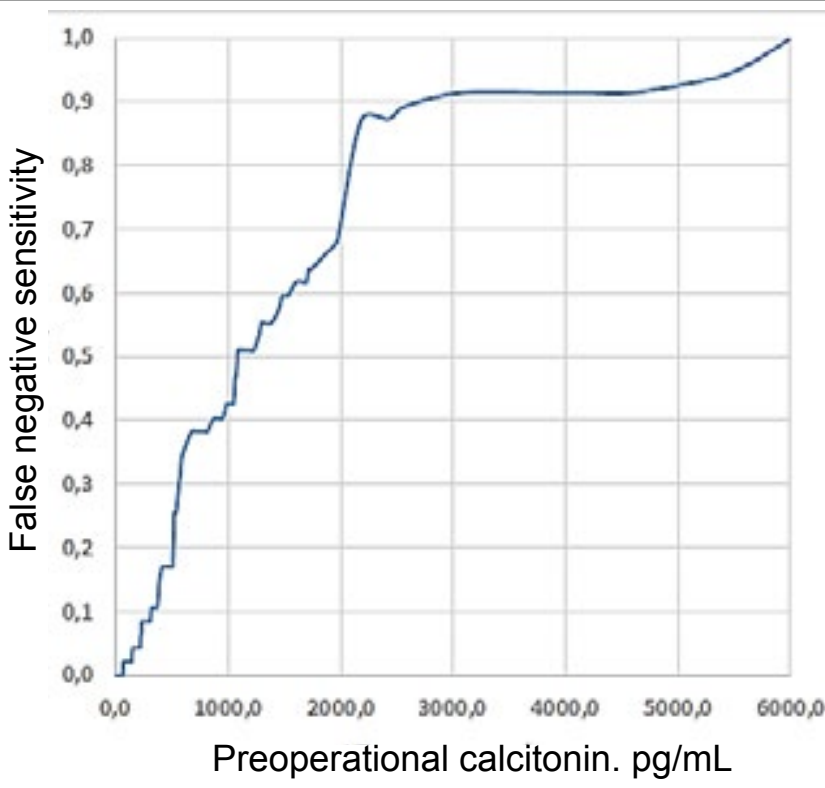

Fig. 2. The probability of metastases missing in a patient depending on the preoperative calcitonin level.

bility of metastases and decide on further treatment tactics to determine the extent of surgery.

To date, surgery remains the only treatment for MTC (Ceolin, et al. 2019). Approximately $35 \%$ of patients with MTC, whose palpation reveals thyroid nodules, already have metastases to the lymph nodes of the neck. About 10\% (7-23\%) have distant metastases at the onset of the disease (Filetti, et al., 2019).

According to Dal Maso, distant metastases occur during their detection in approximately $20-40 \%$ of patients with MTC and they are the leading cause of death associated with the disease (Dal Maso, et al., 2017). Another study confirmed that metastases were the leading cause of death in $>90 \%$ of cancer patients (Fares, et al., 2020).

Due to the high risk of early metastases in this type of cancer in the preoperative stage, the problem of the metastases presence always arises. Existing diagnostic methods (ultrasound is most widely used in hospitals, MSCT, PET-CT) are not high enough diagnostic efficiency due to limited technical capabilities of the equipment, and it largely depends on the experience of the doctor who performs the diagnosis. Thus, false-negative ultrasound findings on the metastases presence are observed in approximately one third of the examined patients (Machens, et al., 2010; Rukanskienè, et al., 2020). According to published data, false-negative ultrasound findings on the metastases presence are more common in the central than in the lateral collector and with the size of metastases $<0.6 \mathrm{~cm}$. Their detection does not exceed $47 \%$ (Huang, et al., 2020). In our study, the number of undiagnosed metastases at the prehospital stage by ultrasound was $64,58 \%$, which illustrates the data on the effectiveness lack of this method (Cheng, et al., 2020). A reliable fact $(p<0.01)$ is the increase in the number of diagnosed metastases to N1a in the preoperative, intraop- 
erative and postoperative stages, from $2,08 \%$ to $4,16 \%$ and 20,84\%, respectively. With N1b ipsilateral metastatic lesions, the number of diagnosed metastases at the diagnostic and treatment stages increases $-31,26 \%$, $47,92 \%$ and $64,58 \%$, for N1b contralaterally $-2,08 \%$, $10,42 \%$ and $14,58 \%$, respectively.

Thus, the ultrasound method allowed to detect metastases in the preoperative stage in almost a third $(35,4 \%)$ of patients with metastatic neck lesions, which were determined in the postoperative period as a result of histopathological findings. Such a low detection rate of MTC metastases allows us to speak about the low efficiency of the ultrasound method and its imperfection. The same opinion is shared by other authors, whose works prove the imperfection of this method, which is one of the reasons for the detection in the postoperative period of elevated calcitonin levels and it reduces the chances of cure (Gimm, et al., 1997; Chen, et al., 2020).

Serum calcitonin in patients with MTC is the important diagnostic, prognostic and predictive biomarker due to its direct relationship with C-cells (Giraudet, et al., 2008; Gambardella, et al., 2019).

We considered the possibility of using preoperative calcitonin levels as a marker of possible metastases. Current recommendations of the American Thyroid Association (ATA) advise to measure the calcitonin level in the blood serum in cases where the cytological conclusion in patients diagnosed (or suspected) of thyroid cancer and the calcitonin level may be a predictor of the disease (Wells, et al., 2015; Silvestre, et al., 2019).

The recommendations of the European Medical Oncology Association (ESMO) generally recommend total thyroidectomy with central and bilateral neck dissection at least at levels IIA, III and IV, even if serum calcitonin levels are between 50 and $200 \mathrm{pg} / \mathrm{mL}$ in patients with negative ultrasound of the neck (Kim \& Kim, 2021). There is no need for prophylactic central neck dissection in small intrathyroid MTC with preoperative calcitonin levels $<20 \mathrm{pg} / \mathrm{mL}$ due to the absence of lymph node metastases risk.

We investigated the significance of preoperative basal blood calcitonin levels as the marker of thyroid metastases presence. Thus, according to our data at the level of calcitonin $<60,7$ no metastases were detected. At the calcitonin level of 60,7 - $358 \mathrm{pg} / \mathrm{mL}$ (cut-off level $137 \mathrm{pg}$ /
$\mathrm{mL}$ ) it is possible to detect metastases in the central collector, but it does not exclude the detection of metastases in the ipsilateral collector. It was proved that the calcitonin level $>58 \mathrm{pg} / \mathrm{mL}$ suggests the presence of MTC metastases in the ipsilateral collector $(\mathrm{AUC}=0,877)$, and at the of calcitonin level $>498 \mathrm{pg} / \mathrm{mL}$ it suggests possible metastases in the contralateral collector $(\mathrm{AUC}=0,832)$. The practical significance of this of calcitonin indicator is to justify the required volume of neck dissection in addition to the mandatory central dissection in order to remove possible expected metastases of thyroid cancer.

Conclusions. Ultrasound is the insufficiently reliable method of metastases verifying in medullary thyroid cancer $(\mathrm{DE}=35,4 \%$ at $\mathrm{d} \mathrm{mts}<0,6 \mathrm{sm})$. In the absence of ultrasound data (or TAPB results) on the presence of metastases to raise awareness of the disease prevalence, to clarify the prognosis of its development it should be used the additional criterion - the calcitonin level.

The basal calcitonin level is the reliable predictor of MTC metastases. Its cut-off level of $137 \mathrm{pg}$ mL indicates the possible presence of metastases in the central group (N1a) (AUC=0.594). The cut-off calcitonin level -358 $\mathrm{pg} / \mathrm{mL}(\mathrm{AUC}=0.793)$ suggests the presence of MTC metastases $(\mathrm{N} 1 \mathrm{a}+\mathrm{N} 1 \mathrm{~b})$. Calcitonin cut-off levels are 358 $\mathrm{pg} / \mathrm{mL}$ for N1b ipsilateral, and $498 \mathrm{pg} / \mathrm{mL}$ - for N1b contralateral (AUC: 0.,877 and 0,832, respectively).

The calculated false negative sensitivity values of the metastases test for different basal calcitonin levels in the preoperative stage in the clinical setting will help the practitioner in deciding on treatment tactics to determine the extent of surgery in patients diagnosed (or suspected) of MTC.

Funding. This study has no external funding.

Conflict of interests. Authors of the article don't have the conflict of interests.

Authors contribution: concept, methodology, formal analysis - P.V., S.V., S.R., M.O.; research, resources, data curation, written - T.O., N.O., K.V., M.O.; original project preparation, review and editing, visualization, supervision, project administration, acquisition of financing - S.V., T.O, K.V., , M.O.

Consent to publication. All authors have read and approved the final version of the manuscript. All authors have agreed to publish this manuscript.

\section{REFERENCES}

Bartz-Kurycki, M. A., Oluwo, O. E., \& Morris-Wiseman, L. F. (2021). Medullary thyroid carcinoma: recent advances in identification, treatment, and prognosis. Therapeutic advances in endocrinology and metabolism, 12, 20420188211049611.

Ceolin, L., da Silveira Duval, M. A., Benini, A. F., Ferreira, C. V., \& Maia, A. L. (2019). Medullary thyroid carcinoma beyond surgery: advances, challenges, and perspectives. Endocrine-related cancer, 26(9), R499-R518.

Chen, L., Sun, W., Qian, K., Guo, K., Sun, T., Wu, Y., \& Wang, Z. (2020). High Ratio of Early Postoperative Calcitonin to Preoperative Calcitonin Could be a Novel Indicator of Poor Prognosis in Patients with Biochemical Incomplete Responses in Sporadic Medullary Thyroid Cancer. Endocrine Practice, 26(7), 738-747.

Cheng, Z., Li, X., An, C., Yu, X., Yu, J., Han, Z., ... \& Liang, P. (2019). The clinical efficacy of ultrasound-guided percutaneous microwave ablation for rib metastases with severe intractable pain: a preliminary clinical study. OncoTargets and therapy, $12,3459$. 
Dal Maso, L., Tavilla, A., Pacini, F., Serraino, D., Van Dijk, B. A. C., Chirlaque, M. D., ... \& Moreno-Iribas, C. (2017). Survival of 86,690 patients with thyroid cancer: a population-based study in 29 European countries from EUROCARE-5. European Journal of Cancer, 77, 140-152.

Fares, J., Fares, M. Y., Khachfe, H. H., Salhab, H. A., \& Fares, Y. (2020). Molecular principles of metastases: a hallmark of cancer revisited. Signal transduction and targeted therapy, 5(1), 1-17.

Filetti, S., Durante, C., Hartl, D., Leboulleux, S., Locati, L. D., Newbold, K., ... \& Berruti, A. (2019). Thyroid cancer: ESMO Clinical Practice Guidelines for diagnosis, treatment and follow-up. Annals of Oncology, 30(12), 1856-1883.

Fleming, J. B., Lee, J. E., Bouvet, M., Schultz, P. N., Sherman, S. I., Sellin, R. V., ... \& Evans, D. B. (1999). Surgical strategy for the treatment of medullary thyroid carcinoma. Annals of surgery, 230(5), 697.

Fugazzola, L., Di Stefano, M., Censi, S., Repaci, A., Colombo, C., Grimaldi, F., ... \& Mian, C. (2021). Basal and stimulated calcitonin for the diagnosis of medullary thyroid cancer: updated thresholds and safety assessment. Journal of Endocrinological Investigation, 44(3), 587-597.

Gambardella, C., Offi, C., Patrone, R., Clarizia, G., Mauriello, C., Tartaglia, E., ... \& Docimo, G. (2019). Calcitonin negative Medullary Thyroid Carcinoma: a challenging diagnosis or a medical dilemma?. BMC endocrine disorders, 19(1), 1-12.

Gimm, O., \& Dralle, H. (1997). Reoperation in metastasizing medullary thyroid carcinoma: is a tumor stage-oriented approach justified?. Surgery, 122(6), 1124-1131.

Giovanella, L., Fontana, M., Keller, F., Verburg, F. A., \& Ceriani, L. (2021). Clinical performance of calcitonin and procalcitonin Elecsys ${ }^{\circledR}$ immunoassays in patients with medullary thyroid carcinoma. Clinical Chemistry and Laboratory Medicine (CCLM), 59(4), 743-747.

Giraudet, A. L., Al Ghulzan, A., Aupérin, A., Leboulleux, S., Chehboun, A., Troalen, F., ... \& Schlumberger, M. (2008). Progression of medullary thyroid carcinoma: assessment with calcitonin and carcinoembryonic antigen doubling times. European Journal of Endocrinology, 158(2), 239-246.

Huang, C., Cong, S., Liang, T., Feng, Z., Gan, K., Zhou, R., ... \& Wang, Q. (2020). Development and validation of an ultrasound-based nomogram for preoperative prediction of cervical central lymph node metastases in papillary thyroid carcinoma. Gland Surgery, 9(4), 956.

Kebebew, E., Ituarte, P. H., Siperstein, A. E., Duh, Q. Y., \& Clark, O. H. (2000). Medullary thyroid carcinoma: clinical characteristics, treatment, prognostic factors, and a comparison of staging systems. Cancer: Interdisciplinary International Journal of the American Cancer Society, 88(5), 1139-1148.

Kiesewetter, B., Riss, P., Scheuba, C., \& Raderer, M. (2021). How I treat medullary thyroid cancer. ESMO open, 6(3), 100183.

Kim, M., \& Kim, B. H. (2021). Current Guidelines for Management of Medullary Thyroid Carcinoma. Journal of Korean Endocrine Society.

Kouvaraki, M. A., Shapiro, S. E., Fornage, B. D., Edeiken-Monro, B. S., Sherman, S. I., Vassilopoulou-Sellin, R., ... \& Evans, D. B. (2003). Role of preoperative ultrasonography in the surgical management of patients with thyroid cancer. Surgery, $134(6), 946-954$.

Kuo, E. J., Sho, S., Li, N., Zanocco, K. A., Yeh, M. W., \& Livhits, M. J. (2018). Risk factors associated with reoperation and disease-specific mortality in patients with medullary thyroid carcinoma. JAMA surgery, 153(1), 52-59.

Machens, A., \& Dralle, H. (2010). Biomarker-based risk stratification for previously untreated medullary thyroid cancer. The Journal of Clinical Endocrinology \& Metabolism, 95(6), 2655-2663.

Master, S. R., \& Burns, B. (2021). Medullary Thyroid Cancer. In StatPearls [Internet]. StatPearls Publishing.

Miller, K. D., Goding Sauer, A., Ortiz, A. P., Fedewa, S. A., Pinheiro, P. S., Tortolero $\square$ Luna, G., ... \& Siegel, R. L. (2018). Cancer statistics for hispanics/latinos, 2018. CA: a cancer journal for clinicians, 68(6), 425-445.

Opsahl, E. M., Akslen, L. A., Schlichting, E., Aas, T., Brauckhoff, K., Hagen, A. I., ... \& Bjøro, T. (2019). The role of calcitonin in predicting the extent of surgery in medullary thyroid carcinoma: a nationwide population-based study in Norway. European thyroid journal, 8(3), 159-166.

Palamarchuk, V.O., Tovkai, O.A., Kuts, V.V., Bodnar, M.R., Lyshchinsky, R.O., Mazur, O.V., Kvitka, D.M., Necha, O.P. (2020). The role of stimulated thyroglobulin in predicting the persistence of papillary thyroid cancer. Clinical Endocrinology and Endocrine Surgery, 2 (70), 17-33.

Park, H., Park, S. Y., Park, J., Choe, J. H., Chung, M. K., Woo, S. Y., ... \& Kim, T. H. (2021). Prognostic Value of Preoperative Serum Calcitonin Levels for Predicting the Recurrence of Medullary Thyroid Carcinoma. Frontiers in endocrinology, 1273.

Pelizzo, M. R., Boschin, I. M., Bernante, P., Toniato, A., Piotto, A., Pagetta, C., ... \& Rubello, D. (2007). Natural history, diagnosis, treatment and outcome of medullary thyroid cancer: 37 years experience on 157 patients. European Journal of Surgical Oncology (EJSO), 33(4), 493-497.

Roman, S., Lin, R., \& Sosa, J. A. (2006). Prognosis of medullary thyroid carcinoma: demographic, clinical, and pathologic predictors of survival in 1252 cases. Cancer: Interdisciplinary International Journal of the American Cancer Society, 107(9), $2134-2142$.

Rukanskienė, D., Veikutis, V., Jonaitienė, E., Basevičiūtė, M., Kunigiškis, D., Paukštaitienė, R., ... \& Boguševičius, A. (2020). Preoperative axillary ultrasound versus sentinel lymph node biopsy in patients with early breast cancer. Medicina, 56(3), 127.

Silvestre, C., Matias, J. S., Proença, H., \& Bugalho, M. J. (2019). Calcitonin screening in nodular thyroid disease: is there a definitive answer?. European thyroid journal, 8(2), 79-82.

Tovkai, O. A., Palamarchuk, V. O., Lishchinsky, P. O., Kuts, V. V., Stotska, L. V., Chirkov, Y. E., \& Zemskov, S. V. (2020). Можливості ультразвукового дослідження щодо виявлення метастазів папілярного раку щитоподібної залози в центральні лімфатичні вузли шиї. Clinical Endocrinology and Endocrine Surgery, (3), 7-15.

Van Heerden, J. A., Grant, C. S., Gharib, H. O. S. S. E. I. N., Hay, I. D., \& Ilstrup, D. M. (1990). Long-term course of patients with persistent hypercalcitoninemia after apparent curative primary surgery for medullary thyroid carcinoma. Annals of surgery, $212(4), 395$.

Wells Jr, S. A., Asa, S. L., Dralle, H., Elisei, R., Evans, D. B., Gagel, R. F., ... \& Waguespack, S. G. (2015). Revised American Thyroid Association guidelines for the management of medullary thyroid carcinoma: the American Thyroid Association Guidelines Task Force on medullary thyroid carcinoma. Thyroid, 25(6), 567-610. 


\section{РОЛЬ КАЛЬЦИТОНІНУ НА ДООПЕРАЦЙНОМУ ЕТАПІ ЯК ПРЕДИКТОРА МЕТАСТАЗУВАННЯ МЕДУЛЯРНОГО РАКУ ЩИТОПОДІБНОЇ ЗАЛОЗИ}

\author{
Паламарчук Володимир ${ }^{1}$ Смоляр Віктор${ }^{1}$, \\ Товкай Олександр ${ }^{1}$, Нечай Олександр ${ }^{1}$, Куц \\ Володимир ${ }^{1,2}$, Січінава Реваз ${ }^{1}$, Мазур Олег ${ }^{1}$ \\ ${ }^{1}$ Український науково-практичний центр \\ ендокринної хірургії, трансплантації \\ ендокринних органів і тканин МО3 України, м. \\ Київ, Україна \\ 2 ДУ«Національний інститут фтизіатрії і \\ пульмонології ім. Ф.Г. Яновського НАМН \\ України», м. Київ, Україна
}

Анотація: метою роботи було проаналізувати виявляємість метастазів МРЩЗ у хворих на лікувально-діагностичних етапах. Дослідити можливість використання показника кальцитоніну сироватки крові для прогнозування можливої наявності метастазів МРЩ3 та визначення об'єму хірургічного втручання. В дослідження включені дані 148 хворих, які проходили хірургічне лікування в Центрі 3 приводу первинно встановленого діагнозу МРЩЗ. Вік хворих варіював від 12 до 83 років, середній вік становив 48,2 $\pm 1,9$ років; розподіл за гендерним типом виглядав наступним чином: чоловіків - 34 (23 \%), жінок- 114 (77\%). Пацієнти були розподілені на дві групи в залежності від наявністі метастазів за даними патоморфологічного дослідження: 1 група (100 (67,6\%) - хворі без метастазів), 2 група (48 (32,4\%) - хворі з наявними локорегіонарними метастазами). Серед 148 досліджуваних хворих на МРЩЗ, у 48 $(32,4 \%)$ за результатом патогістологічного висновку були виявлені метастази в регіонарні лімфатичні вузли, з яких у 10 (6,7\%) паціснтів метастази були локалізовані тільки в центральному колекторі та у 38 $(25,7 \%)$ - в центральному та в латеральних колектоpax. На доопераційному етапі рівень недіагностованих метастазів за результатами УЗД становив 64,58\% (31 хворих). В подальшому на інтраопераційному етапі, при проведенні експрес-гістологічної біопсії кількість недіагностованих метастазів скоротилась до $37,5 \%$ (18 хворих), а в післяопераційному періоді, за результатами патогістологічного висновку, у решти хворих були підтверджені метастази МРЩЗ. Застосування УЗД допомогло виявити метастази у 17 хворих, що становило $35,42 \%$ серед усіх виявлених метастазів. На етапі інтраопераційного дослідження виявляємість метастазів збільшилась і становила 30 $(62,5 \%)$, а в післяопераційному періоді за результатом патогістологічного висновку метастази були підтверджені у 48 хворих (100\%). Кількісні показники як виявлених, так і недіагностованих метастазів на всіх етапах лікувально-діагностичного пошуку є ста-

\section{РОЛЬ КАЛЬЦИТОНИНА НА ДООПЕРАЦИОННОМ ЭТАПЕ КАК ПРЕДИКТОРА МЕТАСТАЗИРОВАНИЯ МЕДУЛЯРНОГО РАКА ЩИТОВИДНОЙ ЖЕЛЕЗЫ}

\author{
Паламарчук Владимир", Смоляр Виктор', \\ Товкай Александр ${ }^{1}$, Нечай Александр ${ }^{1}$, Куц \\ Владимир ${ }^{1,2}$, Сичинава Реваз ${ }^{1}$, Мазур Олег ${ }^{1}$ \\ ${ }^{1}$ Украинский научно-практический центр \\ эндокринной хирургии, трансплантации \\ эндокринных органов и тканей МОЗ Украины, \\ г. Киев, Украина \\ ${ }^{2}$ ГУ «Национальный институт фтизиатрии и \\ пульмонологии им. Ф.Г. Яновского НАМН \\ Украины», г. Киев, Украина
}

Аннотация: целью работы было проанализировать выявляемость метастазов МРЩЖ у больных на лечебно-диагностических этапах. Исследовать возможность использования показателя кальцитонина сыворотки крови для прогнозирования возможного наличия метастазов МРЩЖ и определения объема хирургического вмешательства. В исследование включены данные 148 больных, проходивших хирургическое лечение в Центре по поводу изначально установленного диагноза МРЩЖ. Возраст больных варьировал от 12 до 83 лет, средний возраст составлял 48,2 $\pm 1,9$ лет; распределение по гендерному типу выглядело следующим образом: мужчин - 34 (23\%), женщин - 114 (77\%). Пациенты были распределены на две группы в зависимости от наличия метастазов по данным патоморфологического исследования: 1 группа (100 (67,6\%) - больные без метастазов), 2 группа (48 (32,4\%) - больные с имеющимися локорегионарными метастазами). Среди 148 исследуемых больных МРЩЖ у 48 (32,4\%) по результату патогистологического заключения были обнаружены метастазы в регионарные лимфатические узлы, из которых у 10 (6,7\%) пациентов метастазы были локализованы только в центральном коллекторе и у $38(25,7 \%)-$ в центральном и в латеральных коллекторах. На дооперационном этапе уровень недиагностированных метастазов по результатам УЗИ составил 64,58\% (31 больных). В дальнейшем на интраоперационном этапе, при проведении экспресс-гистологической биопсии, количество недиагностированных метастазов сократилось до 37,5\% (18 больных), а в послеоперационном периоде по результатам патогистологического заключения у остальных больных были подтверждены метастазы МРЩЗ. Применение УЗИ помогло выявить метастазы у 17 больных, что составило 35,42\% среди всех выявленных метастазов. На этапе интраоперационного исследования выявление метастазов увеличилось и составило 30 (62,5\%), а в послеоперационном периоде по результату патогистологического заключения метастазы были подтверждены у 48 больных (100\%). Количественные показатели как выявленных, так и недиагностированных метастазов на всех этапах 
тистично значимими ( $<<0,01)$. Виявляємість метастазів в центральному лімфатичному колекторі (N1a) на доопераційному етапі становила 2,08\%, цей показник збільшився вдвічі (до 4,16\%) після отримання інтраопераційного експрес-гістологічнгого заключення, а при отриманні патогістологічного висновку зріс більше ніж у 10 разів (20,84\%). Ця тенденція зростання виявлення метастазів прослідковувалась і по латеральних колекторах: N1b іпсілатеральні спостерігали у 15 (31,2\%) хворих на доопераційному етапі, їх кількість збільшилась до 23 (47,9\%) інтраопераційно і до 31 (64,6\%) післяопераційно; N1b контрлатеральні спостерігали у 1 (2,1\%), 5 (10,4\%) та 7 (14,6\%) відповідно. Такий низький процент виявлення метастазів на доопераційному етапі методом УЗД спонукав до вивчення рівня кальцитоніну як предиктора можливого метастазування. Нами досліджено значення рівнів доопераційного базального кальцитоніну крові в якості маркеру вірогідності наявності метастазів МРЩЗ. Внаслідок малої чисельності групи $(\mathrm{n}=10)$ з N1а зв’язок кальцитоніну (рівень відсічення 137 пг/мл) з можливою наявністю метастазування був недостатньо вагомий $(\mathrm{AUC}=0,594)$, тоді як у групі з N1b відмічалась більш суттєва різниця. Так, рівні відсічення кальцитоніну 358 пг/мл для N1b іпсілатерального та 498 пг/ мл для N1b контрлатерального виявлення можливих метастазів в колекторах з показниками AUC: 0,877 та 0,832 відповідно, що обгрунтовує необхідність проведення латеральної дисекції шиї крім обов'язкової центральної з метою видалення можливих очікуваних метастазів МРЩЗ. Таким чином, УЗД є недостатньо надійним методом верифікації метастазування при медулярному раку щитоподібної залози (ДЕ = $35,4 \%$ при d mts $<0,6 c \mathrm{c})$. При відсутності У3 даних (або результатів ТАПБ) про наявність метастазів для підвищення інформованості про поширеність захворювання, уточнення прогнозу його розвитку слід використовувати додатковий критерій - рівень кальцитоніну. Рівень базального кальцитоніну $\epsilon$ достовірним предиктором метастазування МРЩЗ. Його рівень відсічення 137 пг/мл вказує на можливу наявність метастазів у центральній групі (N1a) (AUC=0,594). Рівень відсічення кальцитоніну-358 пг/ мл $(\mathrm{AUC}=0,793)$ передбачає наявність метастазування МРЩ3 (N1a+N1b). Рівні відсічення кальцитоніну 358 пг/мл для N1b іпсілатерального, та 498 пг/мл для N1b контрлатерального (AUC: 0,877 та 0,832) відповідно. Розраховані значення контрчутливості тесту на виявлення метастазів для різних рівнів базального кальцитоніну на доопераційному етапі в клінічних умовах допоможуть практикуючому лікарю у прийнятті рішення щодо лікувальної тактики з визначенням обсягу оперативного втручання у хворих з встановленим діагнозом (або підозрою) МРЩЗ.

Ключові слова: кальцитонін, медулярний рак, метастаз, щитоподібна залоза, ROC-аналіз. лечебно-диагностического поиска являются статистически значимыми $(\mathrm{p}<0,01)$. Выявляемость метастазов в центральном лимфатическом коллекторе (N1a) на дооперационном этапе составила 2,08\%, этот показатель увеличился вдвое (до 4,16\%) после получения интраоперационного экспресс-гистологического заключения, а при получении патогистологического заключения вырос более чем в 10 раз (20,84\%). Эта тенденция роста выявления метастазов прослеживалась и по латеральным коллекторам: N1b ипсилатерально наблюдали у 15 (31,2\%) больных на дооперационном этапе, их количество увеличилось до 23 (47,9\%) интраоперационно и до 31 (64,6\%) послеоперационно; N1b контрлатеральные наблюдали у 1 (2,1\%), $5(10,4 \%)$ и $7(14,6 \%)$ соответственно. Такой низкий процент обнаружения метастазов на дооперационном этапе методом УЗИ побуждал изучение уровня кальцитонина как предиктора возможного метастазирования. Нами исследовано значение уровней дооперационного базального кальцитонина крови в качестве маркера вероятности наличия метастазов МРЩЖ. Вследствие малой численности группы (n=10) c N1a связь кальцитонина (уровень отсечки 137 пг/мл) с возможным наличием метастазирования была недостаточно весомой $(\mathrm{AUC}=0,594)$, тогда как в группе с N1b отмечалась более существенная разница. Так, уровни отсечки кальцитонина 358 пг/мл для N1b ипсилатерального, и 498 пг/мл для N1b контрлатерального обнаружения возможных метастазов в коллекторах, с показателями AUC: 0,877 и 0,832 соответственно, что обосновывает необходимость проведения латеральной диссекции шеи, помимо обязательной центральной, с целью удаления возможных ожидаемых метастазов МРЩЖ. Таким образом, УЗИ является недостаточно надежным методом верификации метастазирования при медуллярном раке щитовидной железы (ДЭ $=35,4 \%$ при d mts $<0,6$ см). При отсутствии УЗ данных (или результатов ТАПБ) о наличии метастазов для повышения информированности о распространенности заболевания, уточнении прогноза его развития следует использовать дополнительный критерий - уровень кальцитонина. Уровень базального кальцитонина является достоверным предиктором метастазирования МРЩЖ. Его уровень отсечки 137 пг/мл указывает на наличие метастазов в центральной группе (N1a) (AUC=0,594). Уровень отсечки кальцитонина -358 пг/мл $(\mathrm{AUC}=0,793)$ предполагает наличие метастазирования МРЩЖ (N1a+N1b). Уровни отсечки кальцитонина - 358 пг/мл для N1b ипсилатерального и 498 пг/мл для N1b контрлатерального (AUC: 0,877 и 0,832) соответственно. Рассчитанные значения контрчувствительности теста для выявления метастазов для разных уровней базального кальцитонина на дооперационном этапе в клинических условиях помогут практикующему врачу в принятии решения по лечебной тактике с определением объема оперативного вмешательства у больных с установленным диагнозом (или подозрением) МРЩЖ.

Ключевые слова: кальцитонин, медуллярный рак, метастаз, щитовидная железа, ROC-анализ. 